\title{
Dental Education: Evolving Student Trends
}

\begin{abstract}
Marilyn W. Woolfolk, D.D.S., M.P.H.; Shelia S. Price, D.D.S., Ed.D.
Abstract: As the health care professionals of tomorrow, the students of today are the future of our profession and will shape both dentistry and dental education. To provide historical perspective on today's students, this article summarizes trends in the demographics of allied, predoctoral, and advanced dental students in the United States over the past seventy-five years and reviews efforts made to promote the racial/ethnic diversity of these groups of students. These efforts include legislative initiatives and public and privately funded programs. An outlook for the future considers ways in which new technologies and social networks as well as coordinated interprofessional efforts might further promote the goal of educating students who reflect the diversity of the United States and position the oral health workforce to meet the country's needs.
\end{abstract}

Dr. Woolfolk is Professor of Dentistry and Assistant Dean for Student Services, University of Michigan School of Dentistry; and Dr. Price is Professor of Diagnostic Sciences and Associate Dean for Admissions, Recruitment, and Access, West Virginia University School of Dentistry. Direct correspondence and requests for reprints to Dr. Marilyn Woolfolk, School of Dentistry, University of Michigan, 1011 North University Ave., Ann Arbor, MI 48109-1078; 734-763-3313 phone; winder@umich.edu.

Keywords: dental students, allied dental students, postdoctoral dental students, dental education, gender, minorities, diversity, advanced dental education, dental hygiene education

$\mathrm{I}$ n December 1936, Blauch published the first description of students enrolled in U.S. dental schools in the second issue of the Journal of Dental Education (JDE). ${ }^{1}$ Since then, an important role of the $J D E$ has been to publish regular reports on dental student enrollments along with senior students' opinions of their education and plans after graduation, based on annual surveys conducted by the American Dental Education Association (ADEA). In addition, the journal has published the results of research on many aspects of student life, ranging from how students deal with stress to their attitudes toward patients with special needs to student leadership development programs. Students have also appeared as authors of $J D E$ articles, often reporting on programs and research projects they have initiated. While most of these articles have been about dental students in North America, the journal has also published work regarding students in dental hygiene and advanced dental education programs, as well as students around the world.

Drawing on some of this research and other sources, this article will first provide an overview of demographic trends in the allied, predoctoral, and advanced dental student populations in the United States, giving a picture of who these students are today and how that has changed over the years. It will then turn to recent efforts, especially following the 2000 U.S. surgeon general's report on oral health, ${ }^{2}$ to increase the racial and ethnic diversity of these student populations. After a look at the general purpose underlying these efforts, we will describe some of the national and local programs that have been implemented to address the underrepresentation of African American, Latino/a, and American Indian students. We conclude with some proposals for future actions and reflections on the important role the $J D E$ can play to ensure that the dental profession will be optimally situated to respond to the demands of the future.

\section{Enrollment Trends and Student Demographics}

\begin{abstract}
Allied Dental Students
Haden et al.'s 2001 article "Trends in Allied Dental Education: An Analysis of the Past and a Look to the Future"3 (still the best summary of this subject) points out that allied dental providers have been an integral part of the U.S. dental team since the turn of the nineteenth century. These authors also note that the history of allied dental education mirrors that of dental education: both started with students being educated in apprenticeships and proprietary school settings and then transitioned to formal educational
\end{abstract}


settings in dental schools and community and technical colleges. In May 2001, there were 258 dental assisting programs, 255 dental hygiene programs, and twenty-eight dental laboratory technology programs in the United States. ${ }^{3}$ Currently, there are 333 dental hygiene programs, ${ }^{4}$ fifty-two of which are bachelor's degree-granting programs, ${ }^{5}$ as well as 293 dental assisting programs and twenty dental laboratory technology programs. ${ }^{6}$

Tables 1 to 3 provide an overview of enrollment figures in these allied dental programs since the Haden et al. report. The number of dental hygiene students increased substantially from 12,629 in the 2000-01 academic year to 15,385 in 2009-10 (Table
$1),{ }^{7}$ and the students have remained predominantly female (97 percent for nearly all years). However, the percentage of students of color increased over the decade from 12 to 22 percent due to increases in Latino/a students (5.7 percent to 7.7 percent) and Asian American students (4.6 percent to 7.3 percent). The numbers of dental assisting students in the same time span increased substantially as well, from 6,448 to 10,761 (Table 2), and the majority were also women (about 95 percent). ${ }^{7}$ Over this decade, the percentage of African American dental assisting students increased (12.5 percent to 17.1 percent), as did the percentages of Latino/a students (9.7 percent to 11.7 percent) and Asian American students (2.9 percent

Table 1. Student enrollment in U.S. dental hygiene programs, 2000 to 2010

\begin{tabular}{|c|c|c|c|c|c|c|c|c|}
\hline \multirow[b]{2}{*}{ Year } & \multirow[b]{2}{*}{ Number } & \multirow[b]{2}{*}{$\begin{array}{c}\text { Percentage } \\
\text { Women }\end{array}$} & \multicolumn{6}{|c|}{ Percentage by Race/Ethnicity } \\
\hline & & & Black & Hispanic & $\begin{array}{c}\text { American } \\
\text { Indian }\end{array}$ & Asian & White & Unknown \\
\hline 2000-01 & 12,629 & $97 \%$ & $4.19 \%$ & $5.72 \%$ & $0.55 \%$ & $4.64 \%$ & $88.28 \%$ & $2.61 \%$ \\
\hline 2001-02 & 12,826 & $97 \%$ & $3.73 \%$ & $6.03 \%$ & $0.76 \%$ & $4.65 \%$ & $83.26 \%$ & $1.55 \%$ \\
\hline 2002-03 & 13,031 & $97 \%$ & $4.01 \%$ & $6.38 \%$ & $0.69 \%$ & $4.90 \%$ & $82.33 \%$ & $1.57 \%$ \\
\hline 2003-04 & 13,284 & $98 \%$ & $4.09 \%$ & $6.61 \%$ & $0.71 \%$ & $5.00 \%$ & $81.62 \%$ & $1.98 \%$ \\
\hline 2004-05 & 13,895 & $96 \%$ & $4.21 \%$ & $6.82 \%$ & $0.76 \%$ & $4.97 \%$ & $79.90 \%$ & $2.22 \%$ \\
\hline 2005-06 & 14,012 & $97 \%$ & $3.95 \%$ & $6.72 \%$ & $0.71 \%$ & $5.84 \%$ & $80.20 \%$ & $2.06 \%$ \\
\hline $2006-07$ & 14,795 & $97 \%$ & $4.18 \%$ & $7.50 \%$ & $0.75 \%$ & $6.42 \%$ & $79.27 \%$ & $1.87 \%$ \\
\hline 2007-08 & 15,010 & $97 \%$ & $4.34 \%$ & $7.30 \%$ & $0.85 \%$ & $6.80 \%$ & $78.99 \%$ & $1.73 \%$ \\
\hline 2008-09 & 15,194 & $97 \%$ & $4.41 \%$ & $7.34 \%$ & $0.61 \%$ & $7.04 \%$ & $78.65 \%$ & $1.97 \%$ \\
\hline 2009-10 & 15,385 & $97 \%$ & $4.35 \%$ & $7.70 \%$ & $0.79 \%$ & $7.34 \%$ & $77.87 \%$ & $1.94 \%$ \\
\hline
\end{tabular}

Note: Percentages may not total $100 \%$ because of rounding.

Source: American Dental Association Survey Center. Survey of allied dental education, 2009-10. Chicago: American Dental Association, 2011.

Table 2. Student enrollment in U.S. dental assistant programs, 2000 to 2010

\begin{tabular}{|c|c|c|c|c|c|c|c|c|}
\hline \multirow[b]{2}{*}{ Year } & \multirow[b]{2}{*}{ Number } & \multirow[b]{2}{*}{$\begin{array}{l}\text { Percentage } \\
\text { Women }\end{array}$} & \multicolumn{6}{|c|}{ Percentage by Race/Ethnicity } \\
\hline & & & Black & Hispanic & $\begin{array}{l}\text { American } \\
\text { Indian }\end{array}$ & Asian & White & Unknown \\
\hline 2000-01 & 6,448 & $96 \%$ & $12.53 \%$ & $9.71 \%$ & $1.66 \%$ & $2.85 \%$ & $68.38 \%$ & $4.87 \%$ \\
\hline 2001-02 & 6,707 & $96 \%$ & $13.69 \%$ & $9.02 \%$ & $1.24 \%$ & $2.76 \%$ & $67.03 \%$ & $6.26 \%$ \\
\hline 2002-03 & 7,666 & $94 \%$ & $14.54 \%$ & $9.01 \%$ & $1.54 \%$ & $3.35 \%$ & $66.18 \%$ & $2.30 \%$ \\
\hline 2003-04 & 7,559 & $95 \%$ & $13.63 \%$ & $9.50 \%$ & $1.72 \%$ & $3.81 \%$ & $66.78 \%$ & $2.82 \%$ \\
\hline 2004-05 & 8,030 & $91 \%$ & $11.17 \%$ & $8.43 \%$ & $0.81 \%$ & $3.44 \%$ & $62.85 \%$ & $9.22 \%$ \\
\hline 2005-06 & 8,460 & $89 \%$ & $12.84 \%$ & $8.96 \%$ & $1.06 \%$ & $3.61 \%$ & $58.38 \%$ & $7.91 \%$ \\
\hline 2006-07 & 8,578 & $95 \%$ & $14.70 \%$ & $9.61 \%$ & $1.63 \%$ & $3.63 \%$ & $59.98 \%$ & $10.46 \%$ \\
\hline 2007-08 & 8,923 & $95 \%$ & $13.76 \%$ & $10.21 \%$ & $1.00 \%$ & $4.90 \%$ & $62.75 \%$ & $7.39 \%$ \\
\hline 2008-09 & 9,208 & $95 \%$ & $15.13 \%$ & $11.10 \%$ & $1.23 \%$ & $4.81 \%$ & $60.17 \%$ & $7.57 \%$ \\
\hline $2009-10$ & 10,761 & $95 \%$ & $17.14 \%$ & $11.69 \%$ & $1.13 \%$ & $4.60 \%$ & $55.72 \%$ & $9.80 \%$ \\
\hline
\end{tabular}

Note: Percentages may not total $100 \%$ because of rounding.

Source: American Dental Association Survey Center. Survey of allied dental education, 2009-10. Chicago: American Dental Association, 2011. 
to 4.6 percent). In contrast with these increases, the total number of dental laboratory students dropped slightly from 731 to 692 (Table 3), ${ }^{7}$ and the percentage of women increased from 47 to 56 percent.

\section{Predoctoral Dental Students}

Although Blauch" mentioned "men and women" as practicing dentistry, women in 1936 were much more likely to be dental hygienists or dental assistants than dentists. A picture of the University of Michigan graduating class of 1936 shows forty students, all of whom appear to be white men. The end of World War II led to increases in dental school enrollments as the G.I. Bill made it possible for veterans (mostly men) to pursue higher education. However, the number of women began to slowly increase in the 1950s and 1960s. A gradual change started in the 1970s: 10.4 percent of dental school applicants $(1,364$ of 13,099$)$ were women in 1975 and 15.8 percent $(1,534$ of 9,684$)$ in $1978 .{ }^{8}$ By contrast, the first decade of the twenty-first century saw the percentage of women enrolled students increase from 39 percent in the 2000-01 academic year to 46 percent in 2010-11 (Table 4). ${ }^{9-16}$

In 1945, only 1,533 African American dentists were practicing in the United States, and in 1947 only 313 African American students were attending U.S. dental schools, most of them at the two historically African American dental schools, Howard University and Meharry Medical College. ${ }^{17}$ Given these numbers, it is not surprising that a 1948 report from the National Health Assembly to President Truman concluded that the relative dearth of African American health personnel needed special attention. This report called for immediate action to increase the number of qualified African American applicants to dental schools and to expand their opportunities for dental education.

However, data from 1975 to the present show that the percentages of African American students have not increased substantially. In 1975, 4.1 percent of dental school applicants were African American, ${ }^{8}$ whereas in 2010-11 (Table 4) only 5.6 percent $(\mathrm{N}=1,139)$ were African American and 34 percent $(\mathrm{N}=388)$ of these students were attending Howard and Meharry. ${ }^{18}$ Although African American students are now enrolled in dental schools across the United States, they are still underrepresented at majority institutions when compared with the percentage of African Americans in the population. ${ }^{19}$ One additional trend deserves mention. As the number of women of all races and ethnicities applying and enrolling in dental schools has increased, there has been a significant decline in the number of African American male dental students in the total student population. In 2009, women accounted for 63.5 percent of African American graduates. ${ }^{20}$

Underrepresentation is also a fact of life for Latino/a dental students. In 1975, only 0.9 percent of dental school applicants were Latino/a; ${ }^{8}$ in 1978 the percentage of applicants increased to 4 percent, ${ }^{8}$ but in 2010-11 the percentage of Latino/a enrolled students was still only 6.3 percent, with 13.6 percent of these students attending dental school in Puerto

Table 3. Student enrollment in U.S. dental technician programs, 2000 to 2010

\begin{tabular}{|c|c|c|c|c|c|c|c|c|}
\hline \multirow[b]{2}{*}{ Year } & \multirow[b]{2}{*}{ Number } & \multirow[b]{2}{*}{$\begin{array}{l}\text { Percentage } \\
\text { Women }\end{array}$} & \multicolumn{6}{|c|}{ Percentage by Race/Ethnicity } \\
\hline & & & Black & Hispanic & $\begin{array}{l}\text { American } \\
\text { Indian }\end{array}$ & Asian & White & Unknown \\
\hline 2000-01 & 731 & $47 \%$ & $15.46 \%$ & $13.13 \%$ & $0.14 \%$ & $13.95 \%$ & $44.46 \%$ & $12.86 \%$ \\
\hline 2001-02 & 754 & $43 \%$ & $15.12 \%$ & $11.14 \%$ & 0 & $10.88 \%$ & $48.54 \%$ & $14.32 \%$ \\
\hline 2002-03 & 798 & $47 \%$ & $16.54 \%$ & $13.53 \%$ & $0.13 \%$ & $14.28 \%$ & $51.50 \%$ & $4.01 \%$ \\
\hline 2003-04 & 845 & $43 \%$ & $13.96 \%$ & $7.81 \%$ & $0.95 \%$ & $16.80 \%$ & $42.96 \%$ & $2.37 \%$ \\
\hline 2004-05 & 821 & $41 \%$ & $11.57 \%$ & $11.33 \%$ & $0.12 \%$ & $14.13 \%$ & $40.44 \%$ & $2.07 \%$ \\
\hline 2005-06 & 652 & $50 \%$ & $11.50 \%$ & $11.50 \%$ & $0.15 \%$ & $15.18 \%$ & $45.55 \%$ & $13.80 \%$ \\
\hline 2006-07 & 681 & $49 \%$ & $13.07 \%$ & $14.39 \%$ & $0.44 \%$ & $17.62 \%$ & $44.64 \%$ & $9.84 \%$ \\
\hline 2007-08 & 621 & $51 \%$ & $13.85 \%$ & $10.79 \%$ & $0.32 \%$ & $17.71 \%$ & $43.80 \%$ & $13.53 \%$ \\
\hline 2008-09 & 607 & $54 \%$ & $16.31 \%$ & $9.72 \%$ & 0 & $16.14 \%$ & $46.79 \%$ & $11.04 \%$ \\
\hline 2009-10 & 692 & $56 \%$ & $13.73 \%$ & $11.71 \%$ & $0.29 \%$ & $17.63 \%$ & $43.35 \%$ & $13.29 \%$ \\
\hline
\end{tabular}

Source: American Dental Association Survey Center. Survey of allied dental education, 2009-10. Chicago: American Dental Association, 2011. 
Table 4. Predoctoral students enrolled in U.S. dental schools, 1985 to 2010

\begin{tabular}{|c|c|c|c|c|c|c|c|}
\hline \multirow[b]{2}{*}{ Year } & \multirow[b]{2}{*}{ Number } & \multirow[b]{2}{*}{$\begin{array}{l}\text { Percentage } \\
\text { Women }\end{array}$} & \multicolumn{5}{|c|}{ Percentage by Race/Ethnicity } \\
\hline & & & Black & Hispanic & $\begin{array}{l}\text { American } \\
\text { Indian }\end{array}$ & Asian & White \\
\hline $1985-86$ & 19,554 & & $5.2 \%$ & $5.3 \%$ & $0.3 \%$ & $8.6 \%$ & $80.7 \%$ \\
\hline 1987-88 & 17,868 & & $5.6 \%$ & $6.7 \%$ & $0.3 \%$ & $11.7 \%$ & $75.7 \%$ \\
\hline $1989-90$ & 16,416 & & $6.0 \%$ & $7.8 \%$ & $0.3 \%$ & $14.6 \%$ & $71.3 \%$ \\
\hline 1991-92 & 15,889 & & $5.7 \%$ & $7.3 \%$ & $0.3 \%$ & $16.3 \%$ & $70.2 \%$ \\
\hline 1993-94 & 16,251 & & $6.0 \%$ & $7.0 \%$ & $0.3 \%$ & $17.5 \%$ & $69.2 \%$ \\
\hline $1995-96$ & 17,426 & & $5.5 \%$ & $5.5 \%$ & $0.4 \%$ & $19.7 \%$ & $67.2 \%$ \\
\hline 1997-98 & 16,923 & & $5.2 \%$ & $4.9 \%$ & $0.6 \%$ & $23.0 \%$ & $66.4 \%$ \\
\hline 1999-00 & 17,303 & & $4.7 \%$ & $5.3 \%$ & $0.6 \%$ & $25.0 \%$ & $64.5 \%$ \\
\hline 2000-01 & 17,354 & $39 \%$ & $4.8 \%$ & $5.3 \%$ & $0.6 \%$ & $24.7 \%$ & $64.5 \%$ \\
\hline 2001-02 & 17,498 & $42 \%$ & $4.9 \%$ & $5.9 \%$ & $0.4 \%$ & $23.5 \%$ & $65.3 \%$ \\
\hline 2002-03 & 17,688 & $43 \%$ & $5.1 \%$ & $6.0 \%$ & $0.5 \%$ & $22.8 \%$ & $65.5 \%$ \\
\hline 2003-04 & 17,978 & $44 \%$ & $5.4 \%$ & $5.9 \%$ & $0.4 \%$ & $22.7 \%$ & $65.6 \%$ \\
\hline 2004-05 & 18,313 & $42 \%$ & $5.5 \%$ & $5.8 \%$ & $0.5 \%$ & $22.1 \%$ & $66.1 \%$ \\
\hline 2005-06 & 18,617 & $44 \%$ & $5.7 \%$ & $5.7 \%$ & $0.5 \%$ & $22.0 \%$ & $66.1 \%$ \\
\hline 2006-07 & 19,050 & $43 \%$ & $5.8 \%$ & $5.9 \%$ & $0.6 \%$ & $22.4 \%$ & $65.3 \%$ \\
\hline 2007-08 & 19,292 & $43 \%$ & $5.9 \%$ & $6.3 \%$ & $0.6 \%$ & $22.7 \%$ & $64.5 \%$ \\
\hline 2008-09 & 19,701 & $44 \%$ & $5.8 \%$ & $6.2 \%$ & $0.7 \%$ & $23.3 \%$ & $63.9 \%$ \\
\hline 2009-10 & 20,055 & $47 \%$ & $5.7 \%$ & $6.3 \%$ & $0.6 \%$ & $23.9 \%$ & $63.5 \%$ \\
\hline 2010-11 & 20,346 & $46 \%$ & $5.6 \%$ & $6.3 \%$ & $0.5 \%$ & $22.2 \%$ & $65.3 \%$ \\
\hline
\end{tabular}

Source for numbers and race/ethnic percentages until 2009-10: American Dental Association Survey Center. 2009-10 survey of dental education: academic programs, enrollment, and graduates—volume 1. Chicago: American Dental Association, 2011.

Sources for percentages of women and race/ethnicity percentages for 2010-11: Weaver RG, Valachovic RW, Haden NK. Applicant analysis: 2000 entering class. J Dent Educ 2002;66(3):430-48; Weaver RG, Haden NK, Ramanna S, Valachovic RW. Applicant analysis: 2001 entering class. J Dent Educ 2003;67(6):690-709; Weaver RG, Ramanna S, Haden NK, Valachovic RW. Applicants to U.S. dental schools: an analysis of the 2002 entering class. J Dent Educ 2004;68(8):880-900; Weaver RG, Ramanna S, Haden NK, Valachovic RW. U.S. dental school applicants and enrollees: 2003 and 2004. J Dent Educ 2005;69(9):1064-72; Chmar JE, Weaver RG, Ramanna S, Valachovic RW. U.S. dental school applicants and enrollees, 2005 entering class. J Dent Educ 2007;71(8):1098-123; Okwuje I, Anderson E, Siaya L, Brown LJ, Valachovic RW. U.S. dental school applicants and enrollees, 2006 and 2007 entering classes. J Dent Educ 2008;72(11):1350-91; Okwuje I, Jones G, Anderson E, Valachovic RW. U.S. dental school applicants and enrollees, 2008 entering class. J Dent Educ 2010;74(8):902-25; and Gonzalez G, Anderson E, Novak KF, Valachovic RW. U.S. dental school applicants and enrollees, 2009 entering class. J Dent Educ 2011;75(8):1133-57.

Rico $(\mathrm{N}=175) .{ }^{18}$ These percentages demonstrate that both African American and Latino/a students are significantly underrepresented in U.S. dental schools, ${ }^{19,21}$ considering that, in 2010, 12.6 percent of the U.S. population was African American and 16.3 percent Hispanic/Latino. ${ }^{22}$ In addition, the percentages of American Indian students are very low and have not changed over the years.

On a positive note for diversity, the percentage of Asian American predoctoral dental students has increased significantly from 8.6 percent in 1985-86 to 22.2 percent in 2010-11. Asian American students now have the second highest percentage of applicants to and enrolled students in dental schools by race/ethnicity. ${ }^{16}$ With the surge of students from this minority group, attention thus turned to efforts to increase enrollments from those minority groups that were still underrepresented: African Americans, Latino/as, and American Indians - thus designated "underrepresented minority" (URM) students.

Finally, more graduates of international dental programs have sought to earn U.S. dental degrees, contributing to the diversity of the predoctoral student body. According to survey data from the American Dental Association (ADA), 608 international graduate students were admitted to U.S. dental schools during the 2009-10 year. ${ }^{23}$

\section{Advanced Dental Education}

Blauch mentioned that the first graduate courses in dentistry in the United States were offered 
at the University of Michigan School of Dentistry in 1894. ${ }^{1}$ He noted that progress in advanced instruction had, however, been distressingly slow in the four decades after this first effort, reporting that eight dental schools had seventy-eight graduate students in 1935-36. One of the reasons Blauch stressed the need for expanded graduate instruction was the need for well-trained dental faculty members.

Since 1936, these programs have indeed increased significantly. In 2009-10, 6,095 students were enrolled in some type of advanced education, including General Practice Residency (GPR) and Advanced Education in General Dentistry (AEGD) programs as well as specialty programs. ${ }^{24}$ In addition, twenty-four U.S. dental schools were offering a combined dental/Ph.D. program. The advanced education programs differ substantially in the percentages of women enrolled in them (Table 5). ${ }^{25}$ While 67 percent of students in oral medicine and 62 percent in pediatric dentistry residency programs were women, oral and maxillofacial surgery programs had only 13 percent women. As in predoctoral dental education, the percentages of URM students in graduate programs are substantially lower than the percentages of these groups in the U.S. population. Only 4.9 percent of the students in advanced dental education were African American and only 7.9 percent were Latino/a in 2009-10, while Asian American students were again overrepresented (Table 6).

\section{Importance of Student Diversity}

In the last decade, two seminal reports documented the benefits of diversity in the classroom and as a factor in the improved health of the nation's citizens. The first, in January 1999, was a legal brief, Gurin's “The Compelling Need for Diversity in Education," prepared to defend the University of Michigan against two affirmative action lawsuits. ${ }^{26}$ Gurin's analysis demonstrated that having a diverse classroom setting allows students from European American backgrounds to gain a better understanding of the complexity of racial issues in U.S. society. Given an increasingly diverse population, it seems crucial to educate all future oral health practitioners to ensure they are culturally competent. Diversity is recognized as a quality indicator in the education of health professionals.

The second report, the Sullivan Commission's Missing Persons: Minorities in the Health Professions, ${ }^{27}$ addressed the idea that a diverse student body and workforce will ensure that all patientsindependent of their racial or ethnic status - receive the best possible health care. The Sullivan report made this argument effectively and provided strong empirical evidence in support of it. This report argued that the reasons for increasing the diversity of

Table 5. Percentages of women enrolled in U.S. advanced dental education programs, 2007-08

Type of Program

Percentage Women

Rank by Percentage of Women

Oral medicine

Pediatric dentistry

Oral and maxillofacial radiology

Dental public health

Oral and maxillofacial pathology

General practice residency

Combine prosthodontics-maxillofacial prosthetics

Combined specialty

Maxillofacial prosthetics

Advanced education in general dentistry

Orthodontics and dentofacial orthopedics

Periodontics

Dental anesthesiology

Prosthodontics

Endodontics

Clinical fellowship oral and maxillofacial surgery

Oral and maxillofacial surgery

$\begin{array}{cc}67 \% & 1 \\ 62 \% & 2 \\ 61 \% & 3 \\ 57 \% & 4 \\ 55 \% & 5 \\ 53 \% & 6 \\ 50 \% & 7.5 \\ 50 \% & 7.5 \\ 46 \% & 9 \\ 43 \% & 10 \\ 38 \% & 11 \\ 37 \% & 12 \\ 36 \% & 13 \\ 33 \% & 14 \\ 26 \% & 15 \\ 14 \% & 16 \\ 13 \% & 17\end{array}$

Source: American Dental Association Survey Center. 2007-08 survey of advanced dental education. Chicago: American Dental Association, 2009. 


\begin{tabular}{|c|c|c|c|c|c|}
\hline Year & Black & Hispanic & American Indian & Asian & White \\
\hline $1983-84$ & $2.9 \%$ & $5.6 \%$ & $.20 \%$ & $6.2 \%$ & $76.8 \%$ \\
\hline 1984-85 & $3.0 \%$ & $4.8 \%$ & $.10 \%$ & $6.7 \%$ & $75.7 \%$ \\
\hline $1985-86$ & $3.2 \%$ & $4.8 \%$ & $.10 \%$ & $8.0 \%$ & $74.2 \%$ \\
\hline $1986-87$ & $3.3 \%$ & $4.5 \%$ & $.02 \%$ & $8.7 \%$ & $72.0 \%$ \\
\hline $1987-88$ & $3.4 \%$ & $4.5 \%$ & $.10 \%$ & $8.9 \%$ & $71.7 \%$ \\
\hline 1988-89 & $3.4 \%$ & $5.0 \%$ & $.10 \%$ & $9.2 \%$ & $71.1 \%$ \\
\hline $1989-90$ & $3.5 \%$ & $5.7 \%$ & $.20 \%$ & $9.8 \%$ & $69.5 \%$ \\
\hline $1990-91$ & $4.3 \%$ & $5.7 \%$ & $.10 \%$ & $9.8 \%$ & $67.9 \%$ \\
\hline 1991-92 & $4.6 \%$ & $6.0 \%$ & $.10 \%$ & $10.4 \%$ & $68.1 \%$ \\
\hline 1992-93 & $4.4 \%$ & $6.5 \%$ & $.20 \%$ & $12.1 \%$ & $85.1 \%$ \\
\hline $1993-94$ & $4.1 \%$ & $6.8 \%$ & $.20 \%$ & $13.2 \%$ & $85.4 \%$ \\
\hline 1994-95 & $4.6 \%$ & $7.0 \%$ & $.20 \%$ & $14.0 \%$ & $83.9 \%$ \\
\hline $1995-96$ & $4.6 \%$ & $7.2 \%$ & $.20 \%$ & $15.2 \%$ & $83.6 \%$ \\
\hline $1996-97$ & $4.9 \%$ & $7.3 \%$ & $.20 \%$ & $15.9 \%$ & $83.2 \%$ \\
\hline $1997-98$ & $4.6 \%$ & $7.4 \%$ & $.20 \%$ & $16.8 \%$ & $82.3 \%$ \\
\hline 1998-99 & $5.0 \%$ & $7.5 \%$ & $.20 \%$ & $17.8 \%$ & $80.8 \%$ \\
\hline 1999-2000 & $4.7 \%$ & $7.0 \%$ & $.30 \%$ & $20.0 \%$ & $80.1 \%$ \\
\hline 2000-01 & $5.02 \%$ & $6.85 \%$ & $.18 \%$ & $18.85 \%$ & $78.90 \%$ \\
\hline 2001-02 & $5.27 \%$ & $6.87 \%$ & $.20 \%$ & $21.37 \%$ & $65.40 \%$ \\
\hline 2002-03 & $5.13 \%$ & $6.65 \%$ & $.44 \%$ & $20.94 \%$ & $66.14 \%$ \\
\hline 2003-04 & $5.24 \%$ & $6.80 \%$ & $.47 \%$ & $22.06 \%$ & $64.52 \%$ \\
\hline 2004-05 & $5.01 \%$ & $7.68 \%$ & $.26 \%$ & $22.85 \%$ & $63.53 \%$ \\
\hline 2005-06 & $4.99 \%$ & $7.38 \%$ & $.27 \%$ & $24.02 \%$ & $62.23 \%$ \\
\hline 2006-07 & $5.32 \%$ & $7.64 \%$ & $.18 \%$ & $23.43 \%$ & $62.26 \%$ \\
\hline 2007-08 & $5.30 \%$ & $7.22 \%$ & $.12 \%$ & $23.53 \%$ & $62.46 \%$ \\
\hline 2008-09 & $5.08 \%$ & $7.37 \%$ & $.31 \%$ & $23.69 \%$ & $62.49 \%$ \\
\hline 2009-10 & $4.85 \%$ & $7.94 \%$ & $.22 \%$ & $23.69 \%$ & $62.10 \%$ \\
\hline
\end{tabular}

Note: Percentages may not total $100 \%$ because of rounding.

Source: American Dental Association Survey Center. 2007-08 survey of advanced dental education. Chicago: American Dental Association, 2009.

the health workforce are that increased diversity will improve the overall health of all those in the United States and will strengthen the cultural competence of all health care professionals. This argument is also supported by data from the annual ADEA survey of senior dental students showing that African American and Hispanic students expect to provide care in underserved communities at a higher rate than their white colleagues ${ }^{28}$ and by an earlier study of practice patterns of black dentists in Texas. ${ }^{29}$

\section{Efforts Related to Student Diversity}

\section{Judicial and Legislative Actions}

One of the most significant influences on student demographics in health professions schools was the legal verdict in the Regents of the University of California v. Bakke case in $1978^{30,31}$ which concluded that it was permissible to consider race in admissions decisions for the purpose of attaining the benefits of a diverse student body. This strategy became widely used by educational institutions to increase diversity.

In the 1990s, however, two challenges were brought against the use of race as a factor in the admissions process. In 1996, the Fifth Circuit court in the Hopwood vs. Texas case ruled that pursuit of diversity was not a sufficiently compelling governmental interest to justify considering race in admissions to the University of Texas law school. With this decision, affirmative action programs were banned in the Fifth Circuit, which includes Texas, Louisiana, and Mississippi. At about the same time, the Regents of the University of California system banned the use of race as a factor in admissions, and California voters approved Proposition 209, which banned the use of race or ethnicity in public education, public employ- 
ment, and public contracting decisions. As a result, the number of URM students in health professions programs dropped precipitously in those states. This trend continued in the state of Washington where a voter referendum similar to California's was passed in 1998.

The next legal test was in Grutter vs. Bollinger, in 2003. In this U.S. Supreme Court case, the University of Michigan successfully defended its law school admissions policies, which considered race as one of many factors. Based on research evidence of the educational benefits of diversity for the entire student body along with amicus briefs filed by many business organizations and the military, the court concluded that diversity provides an educational benefit to all students and prepares them to participate in a global community. ${ }^{32,33}$ In that decision, Justice Sandra Day O'Connor wrote that achieving the educational benefits of diversity is a "compelling interest" and the use of race-conscious policies in admissions decisions is permissible if narrowly tailored to achieve that objective. Three years later in 2006, however, the state of Michigan passed a ballot initiative similar to those in California and Washington, banning preferential treatment on the basis of race, ethnicity, gender, or national origin in public education, public contracting, and public employment. Although a few states - currently California, Washington, Michigan, Arizona, and Nebraska - have similar restrictions on affirmative action practices in admissions decisions, public and private institutions in other states are allowed to use race-conscious admission policies, if necessary, in accordance with Grutter as a tool to achieve the compelling educational benefits of student body diversity. ${ }^{32,33}$

To a lesser extent, disability legislation has also contributed to ensuring a diverse student body. Section 504 of the Rehabilitation Act of 1973, which provided protection for persons with disabilities who wanted to enter health professions programs, ${ }^{34}$ was followed by the Americans with Disabilities Act (ADA) of $1990 . .^{35}$ The ADA's guidelines for public and private academic institutions require access for individuals with disabilities who are otherwise qualified and can be reasonably accommodated without undue hardship to the institution. Soon thereafter, health professions schools began to formulate technical standards to ensure that individuals with disabilities could meet qualifications for admissions and matriculation.

\section{Health Careers Opportunity Program}

Although admissions policies, including recent developments in whole-file review, have been the primary strategy for increasing student diversity in the health professions, other important approaches include expanding the pool of applicants through outreach and recruitment programs, developing enrichment programs that enhance the competitiveness of applicants from URM and/or other disadvantaged backgrounds, exposing URM students to the health professions, training all dental students to become culturally competent, and providing students with clinical experiences in community-based educational settings. Some of the most successful programs were funded through the federal Health Careers Opportunity Program (HCOP). ${ }^{36}$

Earlier, after World War II, the recognition that population growth would result in growing demands for health care services led to legislation designed to increase the number of health professionals and to address the underrepresentation of providers from racial minority groups or disadvantaged backgrounds.$^{37}$ With federal support for student loans and scholarships provided under the Health Professions Educational Assistance Act of 1963, enrollments at existing schools expanded, and new schools were established. Overall, significant increases were achieved in the total number of health professions students and practitioners. However, the number of minorities in the health professions remained extremely low. ${ }^{37}$

Additional federal funding was therefore provided beginning in 1971. This funding consisted of grants to undergraduate colleges, health professions schools, and other educational organizations with the purpose of increasing the number of minority students. These institutional grants were designed to help these students get an education in a health profession and overcome the financial and social/cultural barriers that had discouraged them from entering health careers. The Special Health Careers Opportunity Grant (SHCOG) Program and its successor, the Health Careers Opportunity Program (HCOP), were the vehicles for accomplishing this change.

The number of dental schools with HCOP grants increased from two in 1972 to five in 1980. With these grants, the total number of African American dental students grew from 765 to 1,022 from 1972 to 1980 , the number of Hispanic students from 132 
to 519 , and the number of American Indian students from fourteen to fifty-three. ${ }^{37}$ Additionally, distribution of these students expanded to dental schools beyond Meharry, Howard, and the University of Puerto Rico. As early as 1978, a decline in the number of applicants from lower socioeconomic backgrounds also received attention. ${ }^{8}$ Even then, the cost of dental education was seen as a deterrent for these applicants and for some minorities. The impact of financial barriers on the composition of the applicant pool has remained a serious issue.

At the University of Michigan School of Dentistry, the first HCOP grant was acquired in the late 1980s to support the school's commitment to recruit and graduate more URM students. HCOP funding has continued for more than twenty years, with only brief interruptions resulting from occasional lapses in federal support. The HCOP grant funds two summer enrichment programs-Pipeline ${ }^{38}$ and Profile for Success - both for predental students in the early years of their undergraduate education. As a result of the HCOP grant, it was possible to build a strong infrastructure to assist enrolled URM students and prepare potential students to be competitive in the admissions process.

\section{Dental Pipeline Program}

Three key reports published from 1995 to 2004 focused national attention on the need for diversity in the dental workforce. In 1995, the Institute of Medicine (IOM) report Dental Education at the Crossroads: Challenges and Change emphasized the importance of building a dental workforce that reflects the nation's diversity ${ }^{39}$ and urged dental schools to initiate efforts to expand the recruitment of URM students. In 2004, another IOM report, In the Nation's Compelling Interest: Ensuring Diversity in the Health Care Workforce, ${ }^{40}$ again pointed to the importance of increasing the diversity of health care providers. Between these two IOM reports, Oral Health in America: A Report of the Surgeon General drew widespread attention to the fact that certain segments of the population had disproportionate amounts of dental disease and serious challenges when seeking oral health care services. ${ }^{2}$ This report cited an insufficiently diverse oral health workforce as a major contributing factor.

In response to these reports, the Robert Wood Johnson Foundation and The California Endowment launched the Community-Based Dental Education: Pipeline, Profession, and Practice program with the goal of reducing oral health disparities. ${ }^{41,42}$ In partnership with this program, ADEA secured funding from the W.K. Kellogg Foundation (WKKF) to establish the ADEA/WKKF Access to Dental Careers program $^{43}$ to defray educational expenses incurred by dental students recruited in the Pipeline program.

The Pipeline program began in 2002 after fifteen dental schools were selected, through a competitive application process, to participate in the five-year initiative. ${ }^{44-46}$ The project focused on three objectives: 1) to increase the time senior dental students spend in community-based education to sixty days; 2) to increase the cultural competence of all future dental care providers; and 3) to recruit more URM students. ${ }^{47-50}$

For the purpose of the Pipeline program, the term "underrepresented" referred to all groups of students that were underrepresented in the dental profession relative to their representation in the general population. Based on this definition, African American, American Indian, and Latino/a students as well as students from families with annual incomes below 200 percent of the U.S. poverty level were included. ${ }^{48,49}$ A signature component of this national program was the establishment of regional recruitment collaboratives. The five dental schools in California formed one collaborative, and six dental schools in the Northeast established another. These recruitment networks developed common recruitment materials, feeder school affiliations, dental admissions committee workshops, summer enrichment and postbaccalaureate programs, pre-health advisor training, and alliances with dental associations. This collaborative approach to student recruitment helped these schools to achieve more than they could have on their own and can be considered a creative innovation and a model for future recruitment efforts.

In other outcomes of schools involved in the Pipeline program, the average amount of time senior dental students spent in community-based education increased from ten to fifty days, cultural competency training was incorporated into existing curricula, and recruitment programs were strengthened, resulting overall in a 54 percent increase in the enrollment of URM students. ${ }^{49}$ In addition, the schools at Meharry and Howard were able to recruit more Latino/a students into their programs.

Building on the successes of the first phase of the Pipeline program, eight additional dental schools received funding from the Robert Wood Johnson Foundation to embark on Phase II, and the 
five dental schools in California received funds from The California Endowment to continue their efforts for an additional three years. The hope is that the schools involved in this project will be able to sustain and even extend their efforts into the future. Early indicators give reason to be cautiously optimistic.

\section{Student Efforts}

In addition to these publicly and privately funded efforts, it is also worthwhile to consider contributions made by students. Students have always been a vital resource in recruitment efforts and have been effective as role models in their own communities and as mentors for younger students. In the ADA's Student Ambassador Program, ${ }^{51,52}$ for example, they become recruiters in outreach efforts to their communities. This initiative, piloted in October 2006, begins with a one-day program at the ADA Annual Meeting that brings together dental students from across the United States to focus on enhancing diversity in dental education. Dental schools are invited to sponsor one student each year. Most recently, the ADA Career Guidance and Diversity Activities Committee spearheads program planning in collaboration with representatives from such groups as the ADEA Council of Students, Residents, and Fellows, the American Student Dental Association (ASDA), the Hispanic Student Dental Association (HSDA), the Society of American Indian Dentists (SAID) Student Chapter, and the Student National Dental Association (SNDA). Together, these student representatives form an impressive network that tackles issues and identifies venues to help organized dentistry and dental education increase diversity. Students return to their schools armed with resource materials ${ }^{51}$ and a peer network to help their schools adopt new strategies or tailor existing efforts to optimize their recruitment programs.

Students also have a voice in all aspects of dental education through what eventually evolved into the ADEA Council of Students, Residents, and Fellows. A conversation in March 1970 between the Executive Committee of the American Association of Dental Schools (AADS; forerunner of ADEA) and student representatives from twenty-eight of fifty-four dental schools opened a channel for student voices in this educational organization. ${ }^{53,54}$ In 1971 the AADS House of Delegates unanimously approved creation of a Section of Students, which gave students nonvoting representation on the Executive Committee. This important symbolic milestone had limited impact, however, because students were unable to directly participate in AADS governance. In 1973, the section was changed to the Council of Students, and the vice president for students gained voting membership on the AADS Executive Committee (now the ADEA Board of Directors). ${ }^{54,55}$ This council (now the ADEA Council of Students, Residents, and Fellows ${ }^{56}$ ) has facilitated student engagement in the organization for all allied, predoctoral, and advanced dental education students. Since its inception, the council has contributed to the discussion of critical issues of interest to students and boosted transformative change in such areas as curriculum, financial aid, and student-faculty relationships. The integration of students within ADEA governance has been a key source of empowerment and given them a voice on pertinent issues.

\section{National Standards for Cultural Competence}

As demonstrated in multiple articles in the $J D E$ over the years, many dental schools across the nation, under the direction of committed leaders, have made rigorous efforts to enhance their curricula to prepare students to become culturally competent health care providers and to introduce means of more effectively recruiting and retaining URM students. Dental schools that genuinely value students' diverse cultural origins have also established mechanisms to instill inclusive academic environments. A welcoming atmosphere, reinforced with supportive mentors, is an influential factor in improving student diversity.

It is significant that local efforts have received support from national standards related to diversity. Standard 2-16 of the Commission on Dental Accreditation (CODA) standards for dental education programs states: "Graduates must be competent in managing a diverse patient population and have the interpersonal and communication skills to function successfully in a multicultural work environment." The intent of this standard is to prepare students for "dental practice in a diverse society."

A prominent effort that resonates with Standard 2-16 is the U.S. Department of Health and Human Services Office of Minority Health's development of fourteen standards for a national framework for culturally and linguistically appropriate services (CLAS).$^{58}$ Developed to assist accrediting bodies, policymakers, and educators in addressing health inequities in the U.S. population, the CLAS standards 
are organized thematically in three areas: culturally competent care, language access services, and organizational supports for cultural competence. These standards were developed with the following definition of cultural competence as a guide:

Cultural and linguistic competence is a set of congruent behaviors, attitudes, and policies that come together in a system, agency, or among professionals that enables effective work in cross-cultural situations. "Culture" refers to integrated patterns of human behavior that include the language, thoughts, communications, actions, customs, beliefs, values, and institutions of racial, ethnic, religious, or social groups. "Competence" implies having the capacity to function effectively as an individual and an organization within the context of cultural beliefs, behaviors, and needs presented by consumers and their communities. ${ }^{58}$

Dental education has embraced the CLAS standards to make sure it is resulting in culturally competent oral health providers. In the ADEA Competencies for the New General Dentist, for example, cultural competence is part of the supporting foundation knowledge and skills for four of the six competency categories. ${ }^{59,60}$

\section{New Approaches Are Needed}

Legislative acts and court decisions, the assistance of the U.S. government and private foundations, student-driven efforts, and national standards, all in support of individual schools' efforts, have led to significant improvements in the diversity of the dental student population but have not so far resulted in student bodies that are proportional to the U.S. population in their racial, ethnic, and socioeconomic makeup. Thus, in spite of all these efforts, the percentage of URM oral health care providers does not match the percentage of URM groups in the population, and patients from these groups disproportionately suffer from poor oral health and lack access to care. In addition to challenging all allied, dental, and advanced dental education programs to get involved in the currently available efforts to bring about positive change, new approaches should be considered.
Over the years, the $J D E$ has been a valuable source for information about initiatives to increase diversity in the health professions. Recognizing that other health professions suffer similar shortages of URM students, the journal has helped dental educators learn about successes and challenges in other health care fields as well as in dentistry. One signature initiative in medicine that dental educators learned about through the $J D E$ was Project 3000 by 2000 introduced by the Association of American Medical Colleges (AAMC) in 1991..$^{61,62}$ This project aimed to double the annual URM enrollment in U.S. medical schools from 1,485 students in 1990 to 3,000 students in 2000. Could and should the dental education community engage in a similar programmatic effort to address its diversity problem?

One commonly mentioned argument against increasing programmatic efforts to recruit URM dental students is the erroneous perception that there are not sufficient numbers of qualified URM applicants. Table 7 shows that this perception is unfounded. The number of African American and Latino/a students who received bachelor degrees in the sciences and engineering in the United States during the past decade proves there is no shortage of qualified students from these two groups. ${ }^{63}$ This simple fact eliminates the excuse that no efforts can be made to increase the number of URM students. Dental educators have to accept the fact that qualified students are out there; the problem is that dental schools are not attracting them.

So the question becomes what can be done about it? One answer might be to start informing students earlier about careers in the oral health professions, what Bowen and Bok call thinking about how to "shape the river" from an earlier age. ${ }^{64}$ One excellent program to expose precollegiate students to the field of dentistry was initiated in 2009 by ADEA in collaboration with the W.K. Kellogg Foundation. Projects funded by this program used dental and dental hygiene students as mentors for middle and high school students and then engaged these students in educational and community outreach efforts. ${ }^{65-67}$ The outcomes of these programs have been quite promising because these younger students clearly demonstrated increased interest in attending college and considering a career in dental hygiene or dentistry. One primary goal therefore must be to strengthen efforts in K-12 education, which means strengthening their academic preparation as well as informing students about the importance of oral health and the attractiveness of oral health careers. 
Table 7. Number and percentage of students who received bachelor of science or engineering degrees in the United States by race/ethnicity, 1997 to 2006

\begin{tabular}{|c|c|c|c|c|c|c|c|}
\hline \multirow[b]{2}{*}{ Year } & \multirow[b]{2}{*}{$\begin{array}{c}\text { Total } \\
\text { Number }\end{array}$} & \multicolumn{6}{|c|}{ Number and Percentage by Race/Ethnicity } \\
\hline & & $\begin{array}{c}\text { African } \\
\text { American }\end{array}$ & Latino/a & $\begin{array}{l}\text { American } \\
\text { Indian }\end{array}$ & $\begin{array}{c}\text { Asian } \\
\text { American }\end{array}$ & $\begin{array}{l}\text { European } \\
\text { American }\end{array}$ & Unknown \\
\hline 1997 & 388,482 & $\begin{array}{l}29,825 \\
7.68 \%\end{array}$ & $\begin{array}{c}24,445 \\
6.29 \%\end{array}$ & $\begin{array}{l}7,238 \\
1.86 \%\end{array}$ & $\begin{array}{l}32,568 \\
8.38 \%\end{array}$ & $\begin{array}{l}27,480 \\
70.74 \%\end{array}$ & $\begin{array}{c}9,809 \\
7.32 \%\end{array}$ \\
\hline 1998 & 390,618 & $\begin{array}{l}30,751 \\
7.87 \%\end{array}$ & $\begin{array}{r}25,712 \\
6.58 \%\end{array}$ & $\begin{array}{l}7,706 \\
0.61 \%\end{array}$ & $\begin{array}{l}34,004 \\
8.71 \%\end{array}$ & $\begin{array}{l}27,256 \\
69.78 \%\end{array}$ & $\begin{array}{l}10,489 \\
7.93 \%\end{array}$ \\
\hline 2000 & 398,622 & $\begin{array}{c}32,924 \\
8.26 \%\end{array}$ & $\begin{array}{l}27,984 \\
7.02 \%\end{array}$ & $\begin{array}{c}8,431 \\
0.67 \%\end{array}$ & $\begin{array}{l}35,553 \\
8.92 \%\end{array}$ & $\begin{array}{l}27,041 \\
67.84 \%\end{array}$ & $\begin{array}{r}13,950 \\
10.78 \%\end{array}$ \\
\hline 2001 & 400,206 & $\begin{array}{l}33,290 \\
8.32 \%\end{array}$ & $\begin{array}{l}28,321 \\
7.08 \%\end{array}$ & $\begin{array}{c}8,664 \\
0.70 \%\end{array}$ & $\begin{array}{l}36,398 \\
9.09 \%\end{array}$ & $\begin{array}{l}26,784 \\
66.93 \%\end{array}$ & $\begin{array}{c}15,839 \\
12.24 \%\end{array}$ \\
\hline 2001 & 415,611 & $\begin{array}{l}34,796 \\
8.37 \%\end{array}$ & $\begin{array}{l}29,871 \\
7.19 \%\end{array}$ & $\begin{array}{c}8,668 \\
0.64 \%\end{array}$ & $\begin{array}{l}37,452 \\
9.01 \%\end{array}$ & $\begin{array}{l}27,637 \\
66.50 \%\end{array}$ & $\begin{array}{c}18,148 \\
13.88 \%\end{array}$ \\
\hline 2003 & 441,087 & $\begin{array}{l}36,711 \\
8.32 \%\end{array}$ & $\begin{array}{l}32,331 \\
7.33 \%\end{array}$ & $\begin{array}{c}8,242 \\
0.66 \%\end{array}$ & $\begin{array}{l}39,738 \\
9.01 \%\end{array}$ & $\begin{array}{l}29,030 \\
65.82 \%\end{array}$ & $\begin{array}{l}21,380 \\
15.10 \%\end{array}$ \\
\hline 2004 & 455,848 & $\begin{array}{l}38,369 \\
8.42 \%\end{array}$ & $\begin{array}{l}33,437 \\
7.34 \%\end{array}$ & $\begin{array}{c}9,914 \\
0.71 \%\end{array}$ & $\begin{array}{l}41,178 \\
9.03 \%\end{array}$ & $\begin{array}{l}29,657 \\
65.06 \%\end{array}$ & $\begin{array}{l}24,437 \\
16.72 \%\end{array}$ \\
\hline 2005 & 466,003 & $\begin{array}{l}39,283 \\
8.43 \%\end{array}$ & $\begin{array}{l}35,202 \\
7.55 \%\end{array}$ & $\begin{array}{l}9,556 \\
0.68 \%\end{array}$ & $\begin{array}{l}43,030 \\
9.23 \%\end{array}$ & $\begin{array}{l}30,117 \\
64.63 \%\end{array}$ & $\begin{array}{c}25,705 \\
17.17 \%\end{array}$ \\
\hline 2006 & 473,533 & $\begin{array}{c}39,409 \\
8.32 \%\end{array}$ & $\begin{array}{l}36,402 \\
7.69 \%\end{array}$ & $\begin{array}{l}10,046 \\
0.69 \%\end{array}$ & $\begin{array}{c}44,206 \\
9.34 \%\end{array}$ & $\begin{array}{l}30,619 \\
64.66 \%\end{array}$ & $\begin{array}{l}25,947 \\
17.30 \%\end{array}$ \\
\hline
\end{tabular}

Source: National Science Foundation, Division of Science Resources Statistics. Distribution of bachelor's degrees awarded in science and engineering, by citizenship, race/ethnicity, and sex of recipients: 1997-2006. Washington, DC: National Center for Education Statistics, 2009.

A second approach to expanding the pool of potential URM students as well as reaching advisors in high schools and colleges, teachers, and parents is related to current and emerging technologies such as Explore Health Careers (www.explorehealthcareers. org) and GoDental (www.godental.org). Utilizing these communication channels could be combined with existing social networks through such organizations as the NDA, HDA, SAID, and ADA Ambassador program. These social networks could increase collaborative mentoring efforts and involve alumni as well as current students in recruitment activities and outreach efforts to their communities. All dental and dental hygiene students engaged in communitybased education could, for example, be taught to provide oral health education and career information to children and adolescents in the community clinics in which they work.

A final approach focuses on interprofessional activities. Since dentistry and dental hygiene are not the only two health professions that struggle with these issues, capitalizing on networks of academic institutions in medical and nursing schools and developing regional recruitment models would help them reach a larger pool of potential candidates.

\section{Closing Thoughts on the Role of the $J D E$}

The issues in dental education are complex, and the $J D E$ has contributed to the creation of a body of knowledge on the many topics that shape the landscape. As it relates to student demographics, the journal has published reports that give historical perspectives; provided information on recruitment, enrollment, and retention; discussed pipeline issues; advocated for cultural competence; proposed strategies for the future; and provided links to additional resources. It has pushed us to change our vision of the profession and of the student talent that is needed to lead to a new era of excellence in oral health care with accessibility for all.

Going forward, the $J D E$ should continue to keep the discussion related to producing a diverse workforce in the forefront. The journal can be the voice ensuring that all dental schools and dental hygiene programs realize the social contract we have as tax-exempt entities to prepare students from various socioeconomic backgrounds to be able to competently treat the diverse patient population. Since 
1976 , the $J D E$ has published annual applicant reports to help health professions advisors, dental educators, and members of the broader dental community gain a better understanding of the characteristics of the future members of the profession. Thus, the journal has judiciously exercised its responsibility to report trends, chart progress, show dentistry's relevance to other health professions, and transfer knowledge and technology from research that will ultimately influence curricula, admissions, and the content and delivery of courses. In the future, the $J D E$ needs to continue to affirm dentistry's relevance to overall health and promote interprofessional linkages. It should link with existing electronic resources such as ExploreHealthCareers.com, MedEdPORTAL (www.mededportal.org), and others as they promote dentistry and attract talented students from all backgrounds into allied, dental, and advanced dental education programs. As the readership of the journal has become more international through its online presence, it also becomes a platform for scholarly global connections. Ultimately, best practices from North America and countries around the world can be brought to bear as we seek to improve the student experience and enrich the learning environment for all. The powerful role that the $J D E$ can play in this context cannot be underestimated.

\section{Acknowledgments}

We want to thank Mark MacEachern and the Taubman Health Sciences Library at the University of Michigan for help with the literature search; University of Michigan students Michael Hyman and Andrea Carpenter for their help with the tables; and Wendy Ridenour and Theresa Cox from West Virginia University and Sonja Harrison and Dr. Dave Brunson from ADEA for their support for this manuscript. We extend special recognition to Dr. Jeanne Sinkford for her guidance and inspiration.

\section{REFERENCES}

1. Blauch LE. Trends and problems in dental education. J Dent Educ 1936;1(2):63.

2. Oral health in America: a report of the surgeon general. Rockville, MD: U.S. Department of Health and Human Services, National Institutes of Health, National Institute of Dental and Craniofacial Research, 2000.

3. Haden NK, Morr KE, Valachovic RW. Trends in allied dental education: an analysis of the past and a look to the future. J Dent Educ 2001;65(5):480-95.
4. American Dental Hygienists' Association. Entry-level dental hygiene programs. At: www.adha.org/downloads/ edu/Entry_Level_Schools_for_Web_Site.pdf. Accessed: November 2, 2011.

5. American Dental Hygienists' Association. Entry-level dental hygiene programs - bachelor degrees. At: www. adha.org/downloads/edu/Bachelor Degree Schools for Web Site.pdf. Accessed: November 2, 2011.

6. American Dental Association. Dental assisting, hygiene, and lab technology programs in the U.S. At: www.ada. org/5500.aspx. Accessed: November 21, 2011.

7. American Dental Association Survey Center. Survey of allied dental education, 2009-10. Chicago: American Dental Association, 2011.

8. Graham JW, Kinsey RB. An analysis of the decline in dental school applicants, 1975-78. J Dent Educ 1979;43(2):107-14.

9. Weaver RG, Valachovic RW, Haden NK. Applicant analysis: 2000 entering class. J Dent Educ 2002;66(3):430-48.

10. Weaver RG, Haden NK, Ramanna S, Valachovic RW. Applicant analysis: 2001 entering class. J Dent Educ 2003;67(6):690-709.

11. Weaver RG, Ramanna S, Haden NK, Valachovic RW. Applicants to U.S. dental schools: an analysis of the 2002 entering class. J Dent Educ 2004;68(8):880-900.

12. Weaver RG, Ramanna S, Haden NK, Valachovic RW. U.S. dental school applicants and enrollees: 2003 and 2004. J Dent Educ 2005;69(9):1064-72.

13. Chmar JE, Weaver RG, Ramanna S, Valachovic RW. U.S. dental school applicants and enrollees, 2005 entering class. J Dent Educ 2007;71(8):1098-123.

14. Okwuje I, Anderson E, Siaya L, Brown LJ, Valachovic RW. U.S. dental school applicants and enrollees, 2006 and 2007 entering classes. J Dent Educ 2008;72(11):1350-91.

15. Okwuje I, Jones G, Anderson E, Valachovic RW. U.S. dental school applicants and enrollees, 2008 entering class. J Dent Educ 2010;74(8):902-25.

16. Gonzalez G, Anderson E, Novak KF, Valachovic RW. U.S. dental school applicants and enrollees, 2009 entering class. J Dent Educ 2011;75(8):1133-57.

17. Dummett CO, Dummett LD. NDA II: the story of America's second national dental association. Washington, DC: National Dental Association Foundation, 2000.

18. American Dental Association Survey Center. 2009-10 survey of dental education: academic programs, enrollment, and graduates-volume 1. Chicago: American Dental Association, 2011.

19. Sinkford JC, Valachovic RW, Harrison S. Underrepresented minority dental school enrollment: continued vigilance required. J Dent Educ 2004;68(10):112-8.

20. The racial gender gap in U.S. dental schools. Journal of Blacks in Higher Education, September 9, 2011.

21. Sinkford J, Valachovic RW, Harrison S. Continued vigilance: enhancing diversity in dental education. J Dent Educ 2006;70(2):199-203.

22. U.S. Census. Population by Hispanic or Latino origin and by race for the United States: 2000 and 2010. At: www. census.gov/prod/cen2010/doc/p194-171.pdf. Accessed: November 22, 2011. 
23. American Dental Association Survey Center. 2009-10 survey of dental education: tuition, admission, and attrition, volume 2. Chicago: American Dental Association, May 2011:48.

24.American Dental Association Survey Center. 2009-10 survey of advanced dental education. Chicago: American Dental Association, 2011.

25. American Dental Association Survey Center. Survey of advanced dental education. Chicago: American Dental Association, 2008.

26. Gurin P. The compelling need for diversity in education: legal brief for the affirmative action lawsuits Gratz and Hamacher $v$ Bollinger, Duderstadt, the University of Michigan, and the University of Michigan College of LS\&A, U.S. District Court, Eastern District of Michigan, Civil Action No. 97-75231; and Grutter v Bollinger, Lehman, Shields, the University of Michigan and the University of Michigan Law School, U.S. District Court, Eastern District of Michigan, Civil Action No. 97-75928. At: www.umich.edu/ urel/admissions/legal/expert/gurintoc. html. Reprinted in: Mich J Race Law 1999;5(1):363-425.

27. Sullivan Commission. Missing persons: minorities in the health professions. At: www.aacn.nche.edu/Media/pdf/ SullivanReport.pdf. Accessed: November 22, 2011.

28. Chmar JE, Harlow AH, Weaver RG, Valachovic RW. Annual ADEA survey of dental school seniors, 2006 graduating class. J Dent Educ 2007;71(9):1228-5.

29. Solomon ES, Williams CR, Sinkford JC. Practice location characteristics of black dentists in Texas. J Dent Educ 2001;65(6):571-4.

30. Perez TE. The right thing to do: current status of affirmative action programs in higher education. Summary of the symposium on diversity in health professions in honor of Hervert W. Nickens. Bethesda, MD: Institute of Medicine, 2001.

31. Perez TE. Enhancing access to health care and eliminating racial and ethnic disparities in health status: a compelling case for health professions schools to implement raceconscious admissions policies. J Health Care Law Policy 2006;9(1).

32. Tedesco L. The role of diversity in the training of health professionals. In: Smedley BD, Stith AY, Colburn L, Evans $\mathrm{CH}$, eds. The right thing to do, the smart thing to do: enhancing diversity in the health professions. Washington, DC: National Academy Press, 2001:36-56.

33. Tedesco LA. Post-affirmative action Supreme Court decisions: new challenges for academic institutions. J Dent Educ 2005;69(12):1212-21.

34. Rehabilitation Act of 1973. Public Law 93-112, 93rd Congress, H.R. 8070, September 26, 1973. At: www.dotcr. ost.dot.gov/documents/ycr/REHABACT.HTM. Accessed: November 22, 2011.

35. Americans with Disabilities Act of 1990. At: www.ada. gov/archive/adastat91.htm. Accessed: November 22, 2011.

36. U.S. Department of Health and Human Services. Health Careers Opportunity Program. At: https:// grants.hrsa.gov/webExternal/FundingOppDetails. asp?FundingCycleId=79A96BF3-93A1-4595-88970413D6C0DF4D\&ViewMode $=$ EU\&GoBack $=\&$ PrintM ode $=\&$ OnlineAvailabilityFlag $=\&$ pageNumber $=$ \&versio $\mathrm{n}=\& \mathrm{NC}=\&$ Popup $=$. Accessed: December 1, 2011.
37. Testoff A, Aronoff R. The Health Careers Opportunity Program: one influence on increasing the number of minority students in schools of health professions. Public Health Rep 1983;98(3):284-91.

38. Markel G, Woolfolk M, Inglehart MR. Feeding the pipeline: academic skills training for predental students. J Dent Educ 2008;72(6):653-61.

39. Field MJ, ed. Dental education at the crossroads: challenges and change. An Institute of Medicine Report. Washington, DC: National Academy Press, 1995.

40. Smedley BD, Butler SL, Bristow LR, eds. In the nation's compelling interest: ensuring diversity in the health care workforce. An Institute of Medicine Report. Washington, DC: National Academies Press, 2004.

41. Bailit HL. Organization and management of communitybased dental education programs: an overview from the dental pipeline program. J Dent Educ 2010;74(10 Suppl):S9-16.

42. Bailit HL, Formicola AJ, D'Abreu KC, Bau I, Zamora G, Stavisky JS. The dental pipeline program: the national program office perspective. J Dent Educ 2009;73(2 Suppl):S15-S22.

43. Sinkford JC, Valachovic RW, Weaver RG, Harrison SG. ADEA/WKKF Access to Dental Careers Program: supporting a dental pipeline concept and program. J Dent Educ 2010;74(10):1166-9.

44. Price SS, Brunson WD, Mitchell DA, Alexander CJ, Jackson DL. Increasing the enrollment of underrepresented minority dental students: experiences from the dental pipeline program. J Dent Educ 2007;71(3):339-47.

45. Price SS, Crout RJ, Mitchell DA, Brunson WD, Wearden S. Increasing minority enrollment utilizing dental admissions workshop strategies. J Dent Educ 2008;72(11):1268-76.

46. Price SS, Grant-Mills D. Effective admissions practices to achieve greater student diversity in dental schools. J Dent Educ 2010;74(10 Suppl):S87-S97.

47. Formicola A, Bailit H, D’Abreu K, Stavisky J, Bau I, Zamora G, Treadwell H. The dental pipeline program's impact on access disparities and student diversity. J Am Dent Assoc 2009;140(3):346-53.

48. Brunson WD, Jackson DL, Sinkford JC, Valachovic RW. Components of effective outreach and recruitment programs for underrepresented minority and low-income dental students. J Dent Educ 2010;74(10 Suppl):S74-S86.

49. Formicola AJ, D'Abreu KC, Tedesco LA. Underrepresented minority dental student recruitment and enrollment programs. J Dent Educ 2010;74(10 Suppl):S67-S73.

50. Nivet MA. Reflections on the dental pipeline program's efforts regarding underrepresented minority dental students. J Dent Educ 2010;74(10 Suppl):S121-S123.

51. Student ambassador resource kit. Envisioning dentistry's future: leading the way. Summary of the student ambassador pilot program, October 19, 2006, Las Vegas, NV.

52. Ambassador program invitation letter to dental school deans, Dr. Donna Stenberg, Chair, ADA Committee on Career Guidance and Diversity Activities, April 14, 2011.

53. Praetz P. AADS proposal for establishing a Council of Students. J Dent Educ 1972;36(9):28-30.

54. Lynch DP, Duncan S. The council of students: 1970-1980. J Dent Educ 1981;45(3):147-9. 
55. Creath CJ, Hipsher TG, McCauley L. Review of the activities of the AADS Council of Students. J Dent Educ 1987;51(8):486-8.

56. American Dental Education Association. Proceedings of the 2009 ADEA House of Delegates. J Dent Educ 2009;73(7):788-815.

57. Commission on Dental Accreditation. Accreditation standards for dental education programs, 2010. At: www. ada.org/sections/educationAns-Careers/pdfs/predoc.pdf. Accessed: November 22, 2011.

58. National standards for culturally and linguistically appropriate services in health care: final report. Washington, DC: U.S. Department of Health and Human Services, OPHS Office of Minority Health, 2001.

59. ADEA competencies for the new general dentist (as approved by the 2008 ADEA House of Delegates). J Dent Educ 2011;75(7):932-5.

60. ADEA foundation knowledge and skills for the new general dentist (as approved by the 2011 ADEA House of Delegates). J Dent Educ 2011;75(7):936-40.

61. Ready T. Project 3000 by 2000 : toward a unified solution to the problem of minority underrepresentation in the health professions. J Dent Educ 1995;59(6):649-54.

62. Beaudreau J, Terrell C. 3000 by 2000 and beyond: next steps for promoting diversity in the health professions. $\mathrm{J}$ Dent Educ 2003;67(9):1048-52.

63. National Science Foundation, Division of Science Resources Statistics. Distribution of bachelor's degrees awarded in science and engineering, by citizenship, race/ ethnicity, and sex of recipients: 1997-2006. Washington, DC: National Center for Education Statistics, 2009.
64. Bowen W, Bok D. The shape of the river: long-term consequences of considering race in college and university admissions. Princeton: Princeton University Press, 2000.

65. Inglehart MR, Stefanac S, Piskorowski WA, Gwozdek AE, May KB, Woolfolk MW, et al. ADEA/WKKF Dental School Outreach Program (DSOP): serving underserved children and recruiting URM/LI students into the dental health care professions - the role of mentoring and outreach experiences. University of Michigan School of Dentistry End of Project Report, submitted to ADEA on September 15, 2010.

66. Inglehart MR, Stefanac S, Gwozdek AE, May KB, Woolfolk MW, Lucas-Perry E. Lessons learned: dental student outreach program and explore health careers mentoring and social networking website-University of Michigan program. Paper presented at the ADEA Annual Session \& Exhibition, San Diego, CA, March 2011.

67. Inglehart MR, Stefanac SJ, Williams BR, Gwozdek AE, May KB, Woolfolk MW, Piskorowski WA. Recruiting high school students into dentistry and dental hygiene programs: development of a structured educational program and student mentoring. Poster presented at the ADEA Annual Session \& Exhibition, San Diego, CA, March 2011. 